\title{
БІОХІМІЧНІ ЗМІНИ У СИРОВАТАТЦІ КРОВІ ЩУРІВ ПРИ ІШЕМІЧНО-РЕПЕРФУЗІЙНОМУ СИНДРОМІ (ЕКСПЕРИМЕНТАЛЬНЕ ДОСЛІДЖЕННЯ)
}

\author{
๑А. Т. Телев'як, Т. О. Вересюк, П. Р. Сельський, І. І. Боймиструк
}

ДВНЗ «Тернопільський державний медичний університет імені І. Я. Горбачевського МОЗ України»

РЕзЮМЕ. Низкою досліджень доведено, що порушення клітинного обміну, накопичення у нефізіологічних концентраціях продуктів метаболізму і розвиток ендогенної інтоксикації при ішемічно-реперфузійному синдромі (IPC) є вагомими механізмами альтерації тканин.

Мета дослідження - встановити ступінь порушення обмінних процесів на основі аналізу біохімічних змін у сироватці крові щурів при IPC, викликаному накладанням артеріального турнікету на задні кінцівки.

Матеріал і методи. Проведено біохімічне дослідження сироватки крові 36 піддослідних щурів за умов експериментального ішемічно-реперфузійного пошкодження. У контрольній групі було 11 інтактних тварин. Синдром ішемії-реперфузії моделювали шляхом накладання гумових турнікетів SWAT на задні кінцівки тварин. Забір крові здійснювали шляхом кардіотомії верхівки серця, а евтаназію тварин - шляхом декапітації під тіопентал-натрієвим знеболенням. Біохімічні зміни, а саме показники загального білірубіну, тригліцеридів (ТГ), холестерину, креатиніну, загального білка (ЗБ), лужної фосфатази (ЛФ) та рівень трансаміназ (АлАТ, АсАТ) визначали у кожній піддослідній групі. Дослідження показників проводили у міжкафедральній науково-клінічній лабораторії Тернопільського державного медичного університету імені І. Я. Горбачевського реактивами ТОВ НВП «Філісіт-Діагностика», м. Дніпро. Кількісні показники обробляли статистично.

Результати й обговорення. Дослідження показали зростання активності трансаміназ, ЛФ та загального білірубіну, зниження рівня креатиніну та ЗБ у ранній реперфузійний період. Зокрема рівень АлАТ досяг свого найвищого значення в 1 добу, що на 89,5 \% вище групи контролю ( $<<0,05)$, а показник АсАТ був найвищим у тварин 3 2-годинною реперфузією, що $\epsilon$ на 78,73 \% вищим відповідного показника контрольної групи $($ Р $<0,005)$. Рівень ЛФ досяг максимуму на 7 добу, коли був на 45,78 \% вище за показник контрольної групи. Відмічено збільшення концентрації загального білірубіну - у тварин на 7 добу показник перевищував контрольний на 105,3 \% (P<0,005).

Висновки. Зміни біохімічних показників були найбільш виражені у тварин моделі раннього періоду постішемічного ураження (2 година та 1 доба). У сироватці крові піддослідних щурів в цьому періоді спостерігали статистично значуще підвищення вмісту загального білірубіну, зростання рівня трансаміназ та підвищення пересічного показника активності ЛФ, а також відмічалося зниження вмісту ЗБ і креатиніну.

КЛючОВІ СлОВА: ішемічно-реперфузійний синдром, м'язова тканина, біохімічні зміни, метаболізм.

Вступ. Ішемічно-реперфузійний синдром (IPC), або, як його ще називають, «синдром реоксигенації», «реперфузійно-ішемічний», чи «реперфузійний синдром» - це складний мультифакторний процес пошкодження й дисфункції первинно ішемізованих та віддалених від місця ураження тканин у результаті відновлення артеріального кровотоку, що проявляється порушенням цілісності клітинних мембран, активацією процесів апоптозу й некрозу клітин $[2,9]$. Вважають, що найчастіше це пошкодження виникає при гострому порушенні периферійного кровообігу саме у кінцівках [7].

Згідно з статистичними даними, у 15-25 \% постраждалих внаслідок стихійних лих, техногенних катастроф, локальних військових конфліктів чи дорожньо-транспортного травматизму виникає ішемічне здавлювання м'яких тканин, що, у випадку відновлення кровообігу у ішемізованих тканинах, призводить до розвитку IPC, який характеризується вкрай тяжким перебігом і високою летальністю, яка досягає, за різними джерелами, від 30 до $70 \%$ [3].

Найвиразніше IPC проявляється у випадках ураження м'язової тканини, котра має високу чут- ливість до гіпоксії. Синдром супроводжується розвитком метаболічних змін різного ступеня вираженості, тому визначення біохімічних порушень у сироватці крові $\epsilon$ досить актуальним для оцінки ступеня тяжкості ішемічно-реперфузійного пошкодження $[2,6,7,11]$. Вважають що метаболічні розлади та ендогенна інтоксикація, які виникають внаслідок порушення клітинного обміну та накопичення у нефізіологічних концентраціях продуктів метаболізму, $\epsilon$ одним із вагомих механізмів альтерації тканин як на місцевому, так і на системному рівнях $[2,4,8,10]$.

Хоча більшість показників біохімічних лабораторних досліджень, котрі використовуються для визначення ступеня порушення обмінних процесів в організмі, не $\epsilon$ чітко специфічними для IPC, вони дають змогу робити висновки про тяжкість ішемічно-реперфузійного пошкодження в цілому $[2,4]$. При цьому залишаються недостатньо вивченими обмінні порушення у різні періоди патологічного процесу та динаміка таких змін. Потребують подальшого вивчення і біохімічні зміни, що слугують маркерами пошкодження тканин внаслідок тимчасового порушення кровопос- 
Огляди літератури, оригінальні дослідження, погляд на проблему, ювілеї

тачання значного масиву м'язів, а саме підвищеної проникності мікроциркуляторного русла, деструкції клітинних мембран, цитолізу клітин, зниження білковосинезуючої функції печінки, гемолізу еритроцитів та системного ураження внутрішніх органів [8].

Мета роботи - встановити ступінь порушення обмінних процесів на основі аналізу біохімічних змін у сироватці крові щурів при ішемічно-реперфузійному синдромі, викликаному накладанням артеріального турнікету на задні кінцівки.

Матеріал і методи дослідження. Проведено біохімічне дослідження сироватки крові 30 піддослідних щурів за умов експериментального ішемічно-реперфузійного пошкодження. У контрольній групі було 6 інтактних тварин.

Синдром ішемії-реперфузії моделювали шляхом накладання гумових турнікетів SWAT (StretchWrap-And-Tuck) шириною 5-6 мм на задні кінцівки тварини на рівні пахової складки протягом 2 годин під тіопентал-натрієвим знеболенням. Критеріями правильності накладання джгута були відсутність набряку кінцівок і блідість їх забарвлення. Реперфузію здійснювали шляхом відновлення кровообігу у раніше ішемізованих кінцівках після зняття турнікету. Спостереження за тваринами проводили протягом 14 діб.

Експериментальні маніпуляції проводили згідно з основними положеннями «Правил проведення робіт з використанням експериментальних тварин», затверджених указом МОЗ України № 753 від 12 серпня 1997р., Конвенції Ради Європи про охорону хребетних тварин, які використовуються в експериментальних та інших наукових цілях (1986), Директиви ЕСЕ № 609 (1986), Указу МОЗ України № 281 від 01.11.2000 р. «Про заходи з подальшого вдосконалення організаційних норм роботи з використанням експериментальних тварин» та Закону України № 3447-IV «Про захист тварин від жорстокого поводження» (2006).

Під час експерименту тварини були поділені на 5 груп дослідження по 6 щурів у кожній. Модель раннього постішемічного періоду була представлена групами тварин із реперфузійними змінами на 1 і 2 години та 1 добу після зняття турнікету, а модель пізнього постішемічного періоду - на 7 та 14 доби після зняття турнікету. Евтаназію тварин здійснювали шляхом декапітації під тіопентал-натрієвим знеболенням.

Кров для дослідження отримували із верхівки серця піддослідних щурів шляхом кардіотомії перед декапітацією. Сироватку виділяли шляхом центрифугування крові протягом 15 хвилин при 3000 об/хв, після чого охолоджували. Біохімічні зміни, а саме показники вмісту загального білірубіну, тригліцеридів (ТГ), холестерину, креатиніну, загального білка (ЗБ), лужної фосфатази (ЛФ) та рівень трансаміназ (АлАТ, АсАТ) визначали у кожній піддослідній групі. Дослідження даних показників проводили у міжкафедральній науково-клінічній лабораторії Тернопільського державного медичного університету імені І. Я. Горбачевського реактивами ТОВ НВП «Філісіт-Діагностика», м. Дніпро.

Визначення загального білірубіну у сироватці крові проводили за методом Ендрашика, а визначення рівня тригліцеридів - ферментативним методом, згідно з яким утворений в результаті пов'язаних реакцій кольоровий комплекс може бути визначений спектрофотометрично при 365 або 400 нм $[1,8]$. Інтенсивність забарвлення реакційного середовища пропорційна вмісту тригліцеридів у досліджувальному матеріалі $[1,8]$. Дослідження креатиніну проводили за реакцією креатиніну з пікратом натрію за методом Яффе $[1,5,8]$. Вимірювання рівня холестерину проводили за принципом утворення кольорових комплексів згідно з певними реакціями, відповідно інтенсивність забарвлення була пропорційною концентрації його у зразку $[1,8]$. Принцип визначення білків ґрунтувався на тому, що білки із солями міді в лужному середовищі утворюють комплекс з інтенсивним фіолетово-синім забарвленням. Інтенсивність кольору прямо пропорційна концентрації загального білка в зразку $[1,8]$. Визначення лужної фосфатази ґрунтується на тому, що лужна фосфатаза каталізує гідроліз р-нітрофенілфосфату при рН 10,4, із вивільненням р-нітрофенолу та фосфату; чим вища швидкість утворення р-нітрофенолу - тим вища активність лужної фосфатази, що міститься в пробі і вимірюється на фотометрі $[1,5,8]$. Дослідження трансаміназ здійснювали за методом, який ґрунтується на принципі переамінування (трансамінування) та визначенні швидкості окиснення утвореного в ході другої реакції НАДН ${ }_{2}$ яка визначається за зменшенням оптичної щільності реакційного середовища при 340 нм і пропорційна активності АлАТ/АсАТ, що міститься у зразках та вимірюється на фотометрі $[1,5,8]$.

Статистичну обробку матеріалу проводили 3 використанням пакета програм “Microsoft Excel”. Визначали такі показники: середнє арифметичне (M), середнє квадратичне відхилення (б) і помилку середнього арифметичного (m). Статистичну значущість різниці між середніми арифметичними та відносними величинами оцінювали за критерієм Стьюдента-Фішера ( $(\mathrm{t})$.

Результати й обоговорення. У всіх досліджуваних групах проведено порівняльний аналіз рівня ЗБ, ТГ, креатиніну, холестерину, загального білірубіну, показника активності АлАТ, АсАТ та ЛФ. 
Огляди літератури, оригінальні дослідження, погляд на проблему, ювілеї

Вміст загального білка у сироватці крові щурів у 1 годину (1 група) після зняття турнікету ((61,15 $2,83)$ г/л) був на 11,08 \% нижчий, порівняно із від-

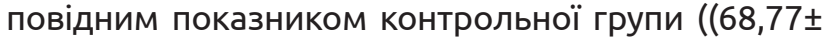
$5,19)$ г/л) $(P>0,05)$. Через 2 години після зняття турнікету (2 група) показник 3Б $((63,12 \pm 1,40)$ г/л) перевищував на 3,22 \% аналогічний показник першої групи $(P>0,05)$ та виявлявся на 8,22 \% нижчим, порівняно з відповідним показником групи контролю $(P>0,05)$. Найнижчого значення вміст ЗБ досяг на 1 добу (3 група щурів) $((58,90 \pm 2,10)$ г/л) - на $14,35 \%$ нижче відповідного показника контрольної групи $(P>0,05)$, на 3,68 \% - відповідного показника 1 групи $(P>0,05)$ та на 6,69 \% - аналогічного показника 2 групи (P>0,05).

У групі тварин моделі пізнього постішемічного періоду вміст ЗБ виявлявся нижчим, ніж у групі контролю. На 7 добу (4 група) спостерігали тенденцію до зростання вмісту ЗБ у сироватці крові експериментальних тварин. Зазначений показник $((61,77 \pm 2,15)$ г/л) виявлявся на 4,87 \% вищим, порівняно з аналогічним показником 3 групи, на 1,01\% вищим, порівняно з відповідним показником 1 групи, проте порівняно з аналогічним показником групи контролю він був нижчим на $10,18 \%$ (P>0,05). На 14 добу після зняття турнікету вміст ЗБ в сироватці крові $((60,75 \pm 2,76)$ г/л) суттєво не відрізнявся від відповідного показника 1 та 3 груп $(P>0,05)$ і був на 11,66 \% нижчим, порівняно з аналогічним показником групи контролю, проте ця відмінність була статистично незначущою ( $>>0,05)$.

Вміст тригліцеридів у сироватці крові тварин 3 моделлю раннього постішемічного періоду зменшувався, досягаючи мінімуму на 1 добу. Так, у 1 групі зазначений показник $((0,61 \pm 0,05)$ ммоль/л) виявлявся на 3,17 \% нижчим за аналогічний показ-

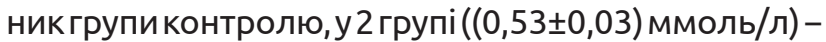
на $15,87 \%$, а у $3((0,52 \pm 0,04)$ ммоль/л) - на $17,46 \%$ нижчим, порівняно з відповідним показником контрольної групи $(P>0,05)$.

На 7 добу (4 група) показник ТГ у сироватці крові щурів досяг максимального рівня $((1,00 \pm$ $0,21)$ ммоль/л), що було на 92,31 \% вище, порівняно з відповідним показником 3 групи, та на 58,73\% вище за відповідний показник контрольної групи тварин $(P>0,05)$. На 14 добу вміст ТГ $((0,72 \pm$ $0,08)$ ммоль/л) зменшився на 28,0 \% відносно попередньої групи і був лише на 14,29 \% вищим за аналогічний показник контрольної групи $(P>0,05)$.

Пересічний показник вмісту креатиніну у сироватці крові щурів $((49,45 \pm 1,60)$ мкмоль/л) зменшився у 1 групі на 7,71\% (P>0,05); у 2 групі відмічено статистично значуще $(P<0,05)$ зменшення вказаного показника $((45,53 \pm 1,48)$ мкмоль/л) на $15,02 \%$ відносно групи контролю. У 3 групі рівень креатиніну $((55,78 \pm 3,71)$ мкмоль/л) досяг максимуму і на
22,51 \% перевищив значення попередньої групи $(\mathrm{P}>0,05)$ та на 4,11\% - показник групи контролю. У 4 та 5 групах тварин концентрація креатиніну в сироватці зменшилась, дані показники відрізнялись між собою незначно $((49,45 \pm 1,54)$ і $(49,92 \pm$ 0,89 мкмоль/л відповідно) і були на $7,71 \%$ та 6,83 \% відповідно нижчими показників контрольної групи, проте ця відмінність не була статистично значущою $(P>0,05)$.

Концентрація холестерину $((1,37 \pm 0,1)$ ммоль/л) у сироватці крові щурів у 1 групі зменшилась на $12,18 \%$, порівняно групою контролю $(P>0,05)$. У 3 групі зазначений показник $((1,77 \pm 0,11)$ ммоль/л) був на 29,2 \% вищий аналогічного показника 2 групи $((1,47 \pm 0,18)$ ммоль/л)) (P>0,05), та на $13,46 \%$ -

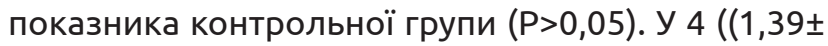
$0,13)$ ммоль/л) та $5((1,38 \pm 0,07)$ ммоль/л) групах рівень холестерину знизився до рівня відповідного показника 1 групи, що, відповідно, на 10,9% та $11,54 \%$ нижче аналогічного показника контрольної групи $(P>0,05)$.

Відмічено статистично значуще збільшення концентрації загального білірубіну в 1 та 2 групах

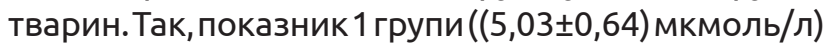
був вищим на $66,56 \%$, у порівняно з показником контрольної групи $(\mathrm{P}<0,05)$. У 2 групі показник загального білірубіну $((6,20 \pm 0,31)$ мкмоль/л) виявлявся вищим, ніж у групі контролю, на 105,3 \% $(P<0,005)$ та на $23,26 \%$ - ніж у 1 групі $(P>0,05)$. У 3

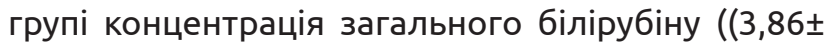
$0,31)$ мкмоль/л) зменшилась відносно попередньої групи на $37,74 \%(P<0,005)$ і була вищою, порівняно з показником контрольної групи, на 27,81 \% $(P>0,05)$. У 4 групі вміст загального білірубіну $((3,69 \pm 0,45)$ мкмоль/л) зменшився, відносно попередньої групи, на 4,4 \% (P>0,05). У 5 групі зазначений показник $((4,19 \pm 0,40)$ мкмоль/л) зріс, порівняно з попередньою, на 13,55 \% (P>0,05), залишаючись при цьому на 38,74 \% вищим, ніж у контрольній групі тварин $(P>0,05)$.

Відмічено зростання показника активності АлАТ у 1, 2 та 3 групах експериментальних тварин. У 1 групі тварин це зростання $((65,1 \pm 7,22)$ од/л) становило $6,03 \%(P>0,05)$. У 2 групі значення даного показника $((82,08 \pm 7,93)$ од/л) на $33,68 \%$ перевищувало відповідне значення групи контролю $(P<0,05)$. Максимального значення показник активності АлАТ ((116,35 $\pm 8,33)$ од/л) досяг у 3 групі тварин: на 78,73 \% вище аналогічних показників 2 групи $(P<0,05)$ та на $89,5 \%$ - групи контролю $(P<0,05)$. Даний показник $((57,75 \pm 2,84)$ од/л) у 4 групі знизився, порівняно з попередньою, на 50,37 \% (P<0,005), досягши на 14 добу реперфузії (5 група) рівня аналогічного показника контрольної групи $(P>0,05)$.

У ранній реперфузійний період у всіх трьох групах відмічали зростання активності АсАТ. У 
Огляди літератури, оригінальні дослідження, погляд на проблему, ювілеї

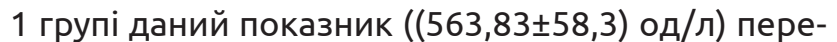
вищував аналогічний показник контрольної групи на 59,23\% (P>0,05), а у 2 групі тварин цей показник $((632,90 \pm 73,0)$ од/л) досяг свого максимуму і був 7 на 8,73 \% вищим відповідного показника у групі контролю ( $<<0,005)$. У 3 групі показник активності АсАТ $((598,78 \pm 55,1)$ од/л) залишався високим, лише на 5,39 \% поступаючись значенню аналогічного показника у попередній групі $(P>0,05)$. У тварин з моделлю пізнього реперфузійного періоду (4 та 5 групи) зазначений показник знизився і наблизився до відповідного показника групи конт-

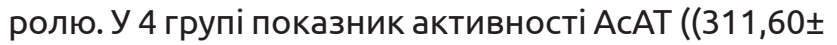
$18,48)$ од/л) виявився на 47,96 \% нижчим, порівняно з аналогічним показником контрольної групи $(P<0,005)$, а у 5 групі $((367,50 \pm 63,46)$ од/л) - лише на 3,78 \% вищим, ніж показник групи контролю $(\mathrm{P}>0,05)$ (табл. 1).

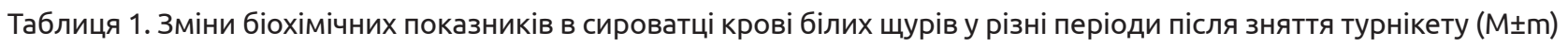

\begin{tabular}{|l|c|c|c|c|c|c|}
\hline \multicolumn{1}{|c|}{ Показник } & Контроль & $\begin{array}{c}1 \text { група, } \\
1 \text { год }\end{array}$ & $\begin{array}{c}2 \text { група, } \\
2 \text { год }\end{array}$ & $\begin{array}{c}3 \text { група, } \\
1 \text { доба }\end{array}$ & $\begin{array}{c}4 \text { група, } \\
7 \text { доба }\end{array}$ & $\begin{array}{c}5 \text { група, } \\
14 \text { доба }\end{array}$ \\
\hline Загальний білок, г/л & $68,77 \pm 5,82$ & $61,15 \pm 2,83$ & $63,12 \pm 1,40$ & $58,90 \pm 2,10$ & $61,77 \pm 2,15$ & $60,75 \pm 2,76$ \\
\hline $\begin{array}{l}\text { Тригліцериди, } \\
\text { ммоль/л }\end{array}$ & $0,63 \pm 0,08$ & $0,61 \pm 0,05$ & $0,53 \pm 0,03$ & $0,52 \pm 0,04$ & $1,00 \pm 0,21$ & $0,72 \pm 0,08$ \\
\hline Креатинін, мкмоль/л & $53,58 \pm 1,51$ & $49,45 \pm 1,60$ & $45,53 \pm 1,48 *$ & $55,78 \pm 3,71$ & $49,45 \pm 1,54$ & $49,92 \pm 0,89$ \\
\hline $\begin{array}{l}\text { Холестерин, } \\
\text { ммоль/л }\end{array}$ & $1,56 \pm 0,10$ & $1,37 \pm 0,10$ & $1,47 \pm 0,18$ & $1,77 \pm 0,11$ & $1,39 \pm 0,13$ & $1,38 \pm 0,07$ \\
\hline $\begin{array}{l}\text { Загальний білірубін, } \\
\text { мкмоль/л }\end{array}$ & $3,02 \pm 0,26$ & $5,03 \pm 0,64 *$ & $6,20 \pm 0,31 * * *$ & $3,86 \pm 0,31 * * * *$ & $3,69 \pm 0,42$ & $4,19 \pm 0,40$ \\
\hline $\begin{array}{l}\text { АлАТ, } \\
\text { од/л }\end{array}$ & $61,40 \pm 4,05$ & $65,1 \pm 7,22$ & $82,08 \pm 7,93 *$ & $116,35 \pm 8,33^{* * *}$ & $57,75 \pm 2,84 * * * *$ & $60,92 \pm 3,14$ \\
\hline $\begin{array}{l}\text { АсАТ, } \\
\text { од/л }\end{array}$ & $354,1 \pm 57,7$ & $563,83 \pm 58,30$ & $632,9 \pm 73,00 * * *$ & $598,78 \pm 55,10$ & $311,60 \pm 18,48 * *$ & $367,5 \pm 63,46$ \\
\hline $\begin{array}{l}\text { ЛФ, } \\
\text { од/л }\end{array}$ & $411,8 \pm 74,9$ & $425,1 \pm 133,3$ & $405,3 \pm 54,5$ & $528,05 \pm 39,1$ & $600,4 \pm 62,5$ & $488,5 \pm 18,1$ \\
\hline
\end{tabular}

Примітки: 1. * - p<0,05 у порівнянні з групою контролю; $2 .{ }^{* *}-$ p $<0,05$ у порівнянні з попередньою групою; 3. *** - p<0,005 у порівнянні з групою контролю; 4. **** - p<0,005 у порівнянні з попередньою групою.

Пересічний показник активності ЛФ у перших двох групах залишався в діапазоні, наближеному до контрольних цифр. Істотне підвищення активності ЛФ спостерігали на 1 добу у 3 групі $((527,95 \pm 39,05)$ од/л) - на 28,2 \% вище, ніж аналогічний показник групи контролю (P>0,05). Максимальна активність ЛФ спостерігалась у 4 групі щурів. Зазначений показник $((600,37 \pm 62,47)$ од/л) був на 12,72 \% вищим, порівняно з аналогічним показником попередньої групи, та на 45,78 \% вищим, ніж відповідний показник групи контролю, хоча ці відмінності не були статистично значущими $(P>0,05)$. У 5 групі тварин даний показник $((488,47 \pm 18,09)$ од/л) зменшився на 18,64 \%, проте залишався на 18,61 \% вищим, ніж у групі контролю ( $P>0,05)$.

Висновки. Виявлені зміни досліджуваних показників підтверджують розвиток реперфузійноішемічного синдрому у досліджуваних тварин. Зміни біохімічних показників сироватки крові були найбільш виражені в 2 та 3 групах тварин моделі раннього періоду ішемічного ураження.

Зниження вмісту креатиніну у 2 групі (реперфузія 2 год) відносно групи контролю $(\mathrm{P}<0,05)$, яке сягало 15,02 \%, вказує на затримку виділення креатиніну в кров у зв'язку з порушенням кровопостачання значного масиву м'язової тканини.
Несуттєве підвищення середнього показника рівня холестерину у сироватці крові (на 13,26 \%), яке виявлялось на 1 добу ішемічного ураження ( $P>0,05)$, свідчить, на нашу думку, про незначний вплив ішемії-реперфузії на обмін холестерину в організмі.

Статистично значуще підвищення вмісту загального білірубіну на 66,54 \% в 1 групі $(P<0,05)$ та на 105,41 \% в 2 групі (Р<0,005) досліджуваних тварин, відносно показників контрольної групи, вказує на розвиток гемолізу еритроцитів внаслідок ушкодження їх клітинних мембран продуктами перекисного окиснення ліпідів.

Статистично значуще підвищення рівня трансаміназ у сироватці крові щурів свідчить про ішемічне ураження значного масиву м'язової тканини, а також про системне ураження внутрішніх органів (насамперед печінки) продуктами метаболізму та перекисного окиснення ліпідів з ішемізованої кінцівки. При цьому зростання АлАТ досягло максимуму у 3 групі тварин на 1 добу (на 89,5 \% вище відповідного показника контрольної групи, $\mathrm{P}<0,005)$, а рівень АсАТ був найвищий в 2 групі щурів (на 78,73 \% вище аналогічного показника контрольної групи, Р<0,005), хоча залишався високим і у 3 групі (на 69,10 \% вище відповідного показника групи контролю, Р>0,05). 
Огляди літератури, оригінальні дослідження, погляд на проблему, ювілеї

Зростання середнього показника активності ЛФ у 3 групі (на 28,2 \%), який досяг максимального значення $((600,37 \pm 62,47)$ од/л) в 4 групі експериментальних тварин, можна пояснити розвитком ураження печінки внаслідок прогресування PIC, хоча збільшення активності ЛФ не було статистично значущим $(P<0,05)$.

У тварин моделі пізнього постішемічного періоду (4 і 5 групи) спостерігали повернення більшості біохімічних показників сироватки крові до значень, близьких до показників контрольної групи. Виняток становив підвищений, відносно групи контролю, рівень тригліцеридів (на 58,73 \% у 4 групі та на 14,29 \% у 5 групі), що, на нашу думку, можна пов'язати з ішемічним ураженням значного масиву м'язової тканини, проте статистично значущої достовірності при цьому не виявлено ( $P>0,05)$.

Перспективи подальших досліджень. Виявлені в результаті біохімічного дослідження сироватки крові щурів закономірності та тенденції можуть бути використані для подальших досліджень та розробки нових напрямків корекції гомеостазу організму при різних видах компресійної травми.

\section{ЛІТЕРАТУРА}

1. Гданський С. М. Особливості змін біохімічних показників крові та показників ендогенної інтоксикації у щурів після поєднаної травми грудної клітки і стегна / С. М. Гданський, Н. Є. Лісничук, І. Є. Герасимюк // Клінічна та експериментальна медицина. - 2014. - Вип. 3, Т. 3 (112). - C. 88-91.

2. Геник С. М. Реперфузійний синдром після реваскуляризації ішемії нижніх кінцівок / С. М. Геник, А. В. Симчич // Серце і судини. - 2016. - № 3. - С. 104-108.

3. Жукова А. А. Состояние протеиназ-ингибиторной системы сыворотки крови и бронхоальвеолярного смыва в динамике развития реперфузионного синдрома и при лечении антиоксидантами и ингибиторами протеиназ / А. А. Жукова // Актуальные проблемы транспортной медицины. - 2013. - Т. II (32-II), № 2. С. 113-117.

4. Келина Н. Ю. Биохимические проявления эндотоксикоза: методические аспекты изучения и оценки, прогностическая значимость (аналитический обзор) / Н. Ю. Келина, Н.В.Безручко, Г. К. Рубцов // Вестник Тюменского государственного университета. - 2012. № 6. - С. 143-147.

5. Кріль І. Й. Біохімічні та імунологічні зміни у крові за умов імунозапального артриту : дис. на здобуття наук. ступеня канд. біологічних наук : спец. 03.00.04 «Біохімія» / Кріль Ірина Йосифівна. - Львів, 2016. - 139 с.

6. Мальченко О.А. Изменение активности неспецифических протеиназ и их ингибиторов в мышечной ткани крыс при экспериментальном реперфузионном синдроме / О. А. Мальченко, Л. В. Анисимова, А. В. Кубышкин // Вісник морфології. - 2014. - № 2, Т. 20. С. 388-391.

7. Мальченко О. А. Патогенетичне обгрунтування підходів до корекції пошкоджень тканин кінцівки при експериментальному реперфузійному синдромі : автореф. дис. на здобуття наук. ступеня кандидата мед. наук: спец. 14.03.04 «Патологічна фізіологія» / О. А. Мальченко. - Київ, 2016. -24 с.

8. Справочник. Физиологические, биохимические и биометрические показатели нормы экспериментальных животных / под ред. В. Г. Макарова, М. Н. Макаровой. - СПб. : Изд-во «Лема», 2013. - 116 с.

9. Drew B. Application of current hemorrhage control techniques for backcountry care: part one, tourniquets and hemorrhage control adjuncts / B. Drew, B. Bennett, L. Littlejohn // Wilderness and Environmental Medicine. - 2015. - № 26. - P. 236-245.

10. Metabolic alterations of skeletal muscle tissue after prolonged acute ischemia and reperfusion / A. Kabaroudis, T. Gerassimidis, D. Karamanos [et al.] // Journal of Investigative Surgery. - 2003. - Vol. 16 (4). P. 219-228.

11. Peripheral perfusion index as an early predictor for central hypovolemia in awake healthy volunteers / M. E. van Genderen, S. A. Bartels, A. Lima [ et al. ] // Anesthesia \& Analgesia. - 2013. - Vol. 116 (2). - P. 351-356.

\section{REFERENCES}

1. Hdanskyi, S.M., Lisnychuk, N.Ye., \& Herasymiuk, I.Ye. (2014). Osoblyvosti zmin biokhimichnykh pokaznykiv krovi ta pokaznykiv endohennoi intoksykatsii u shchuriv pislia poiednanoi travmy hrudnoi klitky i stehna [Features of biochemical blood parameters and indicators of endogenous intoxication in rats after combined injures of the chest and hip]. Visnyk problem biolohii $i$ medytsyny Bulletin of Problems in Biology and Medicine, 3, 3 (112), 8891 [in Ukrainian].

2. Henyk, S.M., \& Symchych, A.V. (2016). Reperfuziinyi syndrom pislia revaskuliaryzatsii ishemii nyzhnikh kintsivok [Reperfusion syndrome after revascularization of the ischemic lower limbs]. Sertse i sudyny-Heart and Vessels, 3, 104-108 [in Ukrainian].

3. Zhukova, A.A. (2013). Sostoyanie proteinaz-ingibitornoy sistemy syvorotki krovi i bronkhoalveolyarnogo smyva $v$ dinamike razvitiya reperfuzionnogo sindroma i pri lechenii antioksidantami i ingibitorami proteinaz [State of the proteinase-inhibitor system of blood and bronchoalveolar lavage fluid in dynamics of reperfusion injury complicated by blood loos and with treatment by antioxidants and protease inhibitors]. Aktualnye problemy transportnoy meditsiny - Actual Problems of Transport Medicine, 2, II, (32-II), 113-117 [in Russian]. 
Огляди літератури, оригінальні дослідження, погляд на проблему, ювілеї

4. Kelina, N.Yu., Bezruchko, N.V., \& Rubtsov, G.K. (2012). Biokhimicheskie proyavleniya endotoksikoza: metodicheskie aspekty izucheniya i otsenki, prognosticheskaya znachimost (analiticheskiy obzor) [Biochemical manifestations of endotoxemia: methodological aspects of the study and evaluation predictive value (analytical review)]. Vestnik Tyumenskogo gosudarstvennogo universiteta - Bulletein of the Tymen State University, 6, 143-147 [in Russian].

5. Kril, I.Y. (2016). Biokhimichni ta imunolohichni zminy u krovi za umov imunozapalnoho artrytu [Biochemical and immunological changes in blood in conditions of the immune-inflammatory arthritis]. Extended abstract of Candidate's thesis. Lviv [in Ukrainian].

6. Malchenko, O.A., Anisimova, L.V., \& Kubyshkin, A.V. (2014). Izmenenie aktivnosti nespetsificheskikh proteinaz i ikh ingibitorov v myshechnoy tkani krys pri eksperimentalnom reperfuzionnom sindrome [Changes activity of nonspecific proteinases and their inhibitors in rats muscular tissue with experimental reperfusion syndrome]. Visnyk morfolohii-Reports of Morphology, 2, (20), 388-391 [in Russian].

7. Malchenko, O.A. (2016). Patohenetychne obhruntuvannia pidkhodiv do korektsii poshkodzhen tkanyn kintsivky

pry eksperymentalnomu reperfuziinomu syndromi [Pathogenetic substantiation of approaches for correcting damaged tissues in experimental lower-limb ischemia-reperfusion syndrome]. Candidate's thesis. Kyiv [in Ukrainian].

8. Makarova, V.G., \& Makarovoy, M.N. (2013). Spravochnik. Fiziologicheskie, biohimicheskie i biometricheskie pokazateli normy eksperimentalnykh zhivotnykh [Reference book. Physiological, biochemical and biometric normal level ranges of experimental animals]. Saint Petersburg: Lema [in Russian].

9. Drew, B., Bennett, B., \& Littlejohn, L. (2015). Application of current hemorrhage control techniques for backcountry care: part one, tourniquets and hemorrhage control adjuncts. Wilderness and Environmental Medicine, 26, 236-245.

10. Kabaroudis, A., Gerassimidis, T., \& Karamanos, D. (2013). Metabolic alterations of skeletal muscle tissue after prolonged acute ischemia and reperfusion. Journal of Investigative Surgery, 16 (4), 219-228.

11. Van Genderen, M.E., Bartels, S.A., \& Lima, A. (2013). Peripheral perfusion index as an early predictor for central hypovolemia in awake healthy volunteers. Anesthesia \& Analgesia., 116 (2), 351-356.

\title{
БИОХИМИЧЕСКИЕ ИЗМЕНЕНИЯ В СЫВОРОТКЕ КРОВИ КРЫС ПРИ ИШЕМИЧЕСКИ- РЕПЕРФУЗИОННОМ СИНДРОМЕ (ЭКСПЕРИМЕНТАЛЬНОЕ ИССЛЕДОВАНИЕ)
}

\author{
๑А. Т. Телевяк, Т. О. Вересюк, П. Р. Сельский, И. И. Боймиструк \\ ГВуз «Тернопольский государственный медицинский университет имени И. Я. Горбачевского \\ МЗ Украины»
}

РЕЗЮМЕ. Рядом исследований доказано, что нарушения клеточного обмена, накопление в нефизиологичных концентрациях продуктов метаболизма и развитие эндогенной интоксикации при ишемически-реперфузионном синдроме (ИРС) являются весомыми механизмами альтерации тканей.

Цель исследования - установить степень нарушения обменных процессов на основании анализа биохимических изменений в сыворотке крови крыс при ИРС, Вызванном наложением артериального жгута на задние конечности.

Материалы и методы. Выполнено биохимическое исследование сыворотки крови 30 подопытных крыс в условиях экспериментального ишемически-реперфузионного повреждения. Контрольная группа состояла из 6 интактных животных. Синдром ишемии-реперфузии моделировали путем наложения резиновых жгутов SWAT на задние конечности животных. Забор крови осуществляли путем рассечения верхушки сердца, а эвтаназию животных - путем декапитации под тиопентал-натриевым наркозом. Биохимические изменения, а именно показатели общего билирубина, триглицеридов (ТГ), холестерина, креатинина, общего белка (ОБ), щелочной фосфатазы (ЩФ) и уровень трансаминаз (АЛТ, АСТ) определяли в каждой подопытной группе. Исследование показателей проводили в межкафедральной научно-клинической лаборатории Тернопольского государственного медицинского университета имени И. Я. Горбачевского реактивами ООО НПП «Филисит-Диагностика», г. Днепр. Количественные показатели обрабатывали статистически.

Результаты и их обсуждение. Исследования показали рост активности трансаминаз, ЩФ и общего билирубина, снижение уровня креатинина и ОБ в ранний реперфузионный период. В частности, уровень АЛТ достиг своего наивысшего значения в 1 сутки, что на 89,5\% выше группы контроля $(P<0,05)$, а показатель $A C T$ наиболее высоким был у животных с 2-часовой реперфузией, что на 78,73 \% выше соответствующего показателя контрольной группы (Р<0,005). Уровень ЩФ достиг своего максимума на 7 сутки, что на 45,78 \% выше показателя контрольной группы. Отмечено увеличение концентрации общего билирубина - у животных на 7 сутки показатель превышал контрольный на 105,3 \% (P<0,005).

Выводы. Изменения биохимических показателей были наиболее выражены у животных модели раннего периода постишемического поражения (2 час и 1 сутки). В сыворотке крови подопытных крыс в этом периоде наблюдалось статистически значимое повышение содержания общего билирубина, уровня трансаминаз и повышение среднего показателя активности ЩФ, а также снижение содержания ОБ и креатинина.

КЛючЕВЫЕ СЛОВА: ишемически-реперфузионный синдром, мышечная ткань, биохимические изменения, метаболизм. 


\section{Огляди літератури, оригінальні дослідження, погляд на проблему, ювілеї \\ BIOCHEMICAL CHANGES IN BLOOD SERUM OF RATS WITH REPERFUSION-ISCHEMIC SYNDROME (THE EXPERIMENTAL STUDY)}

\section{A. T. Televiak, T. O. Veresiuk, P. R. Selskyy, I. I. Boymystruk \\ I. Horbachevsky Ternopil State Medical University}

SUMMARY. A number of studies have shown that violation of cellular metabolism, accumulation in non-physiological concentrations of metabolic products, and development of endogenous intoxication in ischemic-reperfusion syndrome (IRS) are important mechanisms for tissue alteration.

The aim of the study - to determine the degree of metabolic disturbances based on the analysis of biochemical changes in the blood serum of the rats with IRS, caused by overlaying the arterial tourniquet on the hind limbs.

Material and Methods. Under conditions of the experimental ischemic-reperfusion, the biochemical examination of the blood serum of 30 experimental rats injury was conducted. In the control group there were 6 intact animals. The ischemia-reperfusion syndrome was modeled by applying of SWAT rubber tourniquet on the hind limbs of the animals. Blood collection accomplished by means of cardiotomy. Euthanasia of the animals was performed by decapitation under the thiopental-sodium anestesia. The biochemical changes, namely the indices of total bilirubin, triglycerides (TG), cholesterol, creatinine, total protein (TP), alkaline phosphatase (AF), and the level of transaminases (AIAT, AsAT) were determined in each group. The study of indicators was carried out in the inter-departmental scientific-clinical laboratory of I. Horbachevsky Ternopil State Medical University by reagents of Scientific-Production Enterprise "Filisit-Diagnostika" LLC of the city of Dnipro. The quantitative indicators were processed statistically.

Results and Discussion. Researches have shown an increasing activity of transaminases, AF and total bilirubin and decreasing concentration of creatinine and TP in the early reperfusion period. In particular, the level of AlAT reached its the highest value in the first day, which was $89.5 \%$ higher than the control group $(P<0.05)$, and the AsAT index was the highest in the animals with 2-hour reperfusion, which was $78.73 \%$ higher corresponding indicator of the control group $(P<0.005)$. AF reached its maximum on the 7 th day, which is $45.78 \%$ higher than the index of the control group. Increase in concentration of total bilirubin was noted in the animals on the 7 th day- the indicator exceeded the control by $105.3 \%$ $(\mathrm{P}<0.005)$

Conclusions. Changes in biochemical indices were most pronounced in the animals of the early period model of postischemic lesions (2nd hour and 1st day). In this period, in the blood serum of the experimental rats, a statistically significant increase in the content of total bilirubin level, a rise in the transaminases level, increase in average AF activity, and a decrease in the content of TP and creatinine were observed.

KEY WORDS: ischemic-reperfusion syndrome; muscle tissue; biochemical changes; metabolism.

Отримано 17.02.2018 